\title{
Seismic Retrofitting of RC Structures with Exterior Shear Walls and Bracing
}

\author{
Bharat Diliprao Daspute. \\ PG Student (Structural Engineering), \\ MGM's JNEC, Aurangabad, 431002, Maharashtra, India
}

\author{
L. G. Kalurkar \\ Assistant Professor, Dept of Civil Engineering \\ MGM's JNEC Aurangabad \\ Aurangabad, Maharashtra, India
}

\begin{abstract}
Many existing reinforced concrete framework in world that is present are insufficient for earthquakes. Recent earthquakes that occurred during last ten years have suggested that significant damage happened wasn't specifically on account of methods of earthquakes but on account of bad performance of construction during earthquake. The current building system, that were design and constructed according to first codal provisions, don't satisfy needs of present seismic design and code methods. It's realized that the best technique of lowering the danger of harmful structure is seismic retrofitting. In the recent past, there's a tremendous enhancement of retrofitting techniques. This analysis highlights the concepts of evaluating and also retrofitting of structure against seismic events. A 3 dimensional R.C. frame fashioned with linear elastic compelling analysis. The computer software program ETab is utilized for dynamics analysis strategy is applied to look at the functionality of a reinforced concrete building. The various retrofitting techniques including steel and concrete application and jacketing of fiber reinforced polymer (FRP) composites that happened to be utilized to enhance the load bearing capacity of specific structure elements are highlighted and techniques including shear wall space plus shear cores that enables you to improve general balance of buildings. Most retrofitting techniques are going to result a rise in stiffness as well as somewhat enhance in mass that causes in return a shorter period. Shortening in period of vibration quite often results an increased ductility and strength of retrofitted structure. Consequently, a proposed retrofit program could be believed to achieve success in case it results an increased strength and also ductility capability of the structure that is higher compared to the requirements required by earthquakes.
\end{abstract}

Keywords-Retrofitting, Seismic Events, FRP, Jacketing, Stiffness

\section{INTRODUCTION}

\subsection{General}

Seismic Retrofitting Techniques are required for concrete constructions which are vulnerable to damage and failures by seismic forces. In the past thirty years, moderate to severe earthquakes occurs around the world every year. Such events lead to damage to the concrete structures as well as failures. Thus, the aim is to focus on a few specific procedures which may improve the practice for the evaluation of seismic vulnerability of existing reinforced concrete buildings of more importance

and fortheirseismicretrofittingbymeansofvariousinnovativetechniqu essuchasbaseisolationandmass reduction. So Seismic Retrofitting is a collection of mitigation technique for Earthquake engineering. It is of utmost importance for historic monuments, areas prone to severe earthquakes and tall or expensive structures.Older construction, designed according to earlier codes, may not comply with current seismic regulations since focus used to be primarily on warranting sufficient capacity for gravity loads alone. Moreover, the past thirty years have witnessed such a significant increase of knowledge in the field of earthquake engineering that even relatively modem structures may no longer meet the prerequisites of constantly-developing regulations.

\subsection{Earthquake Design Philosophy}

The engineering intention behind earthquake resistant design is not to make earthquake-proof buildings that will not get damaged even during the rare but strong earthquake; such buildings will be too robust and also too expensive. Instead, the engineers make buildings to resist the effects of ground shaking, although they may get damaged severely but would not collapse during the strong earthquake. Thus, safety of human life and contents inside of the building are assured.The earthquake design philosophy may be summarized as follows;

(i)Under minor but frequent shaking, the main members of the building resist earthquake impact without being damaged (staying at elastic range); however building parts that do not carry load may sustain repairable damage.

(ii)Under moderate but occasional shaking, the main members may sustain some repairable damage, while the other parts of the building may be damaged even may need replacement.

(iii)Under strong but rare shaking, the main members may sustain severe (even irreparable) damage, but the building should not collapse.

\subsection{Seismic Retrofitting techniques}

- Earthquake creates great devastation in terms of life, money and failures of structures.

- Upgrading of certain building systems (existing structures) to make them more resistant to seismic activity (earthquake resistance) is really of more importance.

- Structures can be (a) Earthquake damaged, (b) Earthquake vulnerable

\subsection{Seismic Retrofitting Of Concrete Structures: \\ Definition:}

It is the modification of existing structures to make them more resistant to seismic activity, ground motion, or soil failure due to earthquakes.

The retrofit techniques are also applicable for other natural hazards such as tropical cyclones, tornadoes, and severe winds from thunderstorms.

\subsection{Need For Seismic Retrofitting:}

- To ensure the safety and security of a building, employees, structure functionality, machinery and inventory 
- Essential to reduce hazard and losses from non-structural elements.

- Important buildings must be strengthened whose services are assumed to be essential just after an earthquake like hospitals.

\subsection{Problems Faced By Structural Engineers Are:}

Lack of standards for retrofitting methods - Effectiveness of each methods varies a lot depending upon parameters like type of structures, material condition, amount of damage etc.,

\subsection{Basic Concept Of Retrofitting}

- Up gradation of lateral strength of structure

- Increase in ductility of structure

- Increase in strength and ductility

\subsection{Problem Statement}

The main reason for this particular study is increasing proficiency and knowledge in earthquake resistant design plus seismic rehabilitation of existing buildings and also in order to increase familiarity with modeling \& analyzing buildings against seismic loads by utilizing computer software

\subsection{Objective}

The objectives of this particular analysis are:

(i) To explore the consequences of earthquake forces on structures and literature search on earthquake resistant design

(ii) To assess the feasibility of seismic evaluation of advantages and buildings of using the retrofit measures designed for strengthening

(iii) To evaluate performance based design and compare various seismic analysis method

\section{METHODOLOGY}

To gather various types of work on seismic analysis of highrise structures and increasing lateral stiffness of the system various papers, thesis and research articles were studied thoroughly and referred. The idea behind doing literature review was to collect data and have understanding on different methods and approaches that can be used, to clear understand the software requirement of the project. Literature review was done to have thorough guidelines during the entire project work.

\subsection{Data Collection}

The data's were obtained from the college. The earthquakes considered in this work are time history of ground motion as per IS 1893:2002 (Part-I), at particular location.

\subsection{Methodology Adopted}

As discussed in the scope of the work, the entire work is divided into three parts:

\section{$>\quad$ Analysis of bare frame}

$>$ Analysis of the braced frames.

$>$ Analysis of the frame with shear wall

For analysis a 12 stories high building is modeled in Etab as a space frame. The building is does not represent any real existing building. The building is unsymmetrical with the span more along $\mathrm{Z}$ direction than along $\mathrm{X}$ direction. The building rises up to $42 \mathrm{~m}$ along $\mathrm{Y}$ direction and spans $15 \mathrm{~m}$ along $\mathrm{X}$ direction and $20 \mathrm{~m}$ along $\mathrm{Z}$ direction .The building is analyzed by Response Spectrum Analysis, which is a linear dynamic analysis. Dynamic Analysis is adopted since it gives better results than static analysis. The specifications of the frame are given in Table 3.1. and the plan and the model of the building is shown in Fig. 4and Fig.5 respectively. In the entire course work $\mathrm{X}$ and $\mathrm{Z}$ are taken as the horizontal axes and $\mathrm{Y}$ as the vertical axes.

Table.2.1. Specifications of the building

\begin{tabular}{|c|c|}
\hline Specifications & Data \\
\hline Storey Height & $3.5 \mathrm{~m}$ \\
\hline No. of bays along X direction & 3 \\
\hline No. of bays along X direction & 4 \\
\hline Bay Length along X direction & $5 \mathrm{~m}$ \\
\hline Bay Length along Z direction & M 30 \\
\hline Concrete grade used & $0.45 \mathrm{~m} \mathrm{X} 0.25 \mathrm{~m}$ \\
\hline Columns & $0.40 \mathrm{~m} \mathrm{X} 0.25 \mathrm{~m}$ \\
\hline Longitudinal Beams & $0.35 \mathrm{~m} \mathrm{X} 0.25 \mathrm{~m}$ \\
\hline Transverse Beams & $0.1 \mathrm{~m}$ \\
\hline Slab Thickness & $25 \mathrm{kN} / \mathrm{m} 3$ \\
\hline Unit Weight of Concrete & $3.5 \mathrm{kN} / \mathrm{m} 3$ \\
\hline Live Load & $\mathrm{IV}$ \\
\hline Zone & Hard Soil \\
\hline Soil Conditions & $5 \%$ \\
\hline Damping Ratio &
\end{tabular}

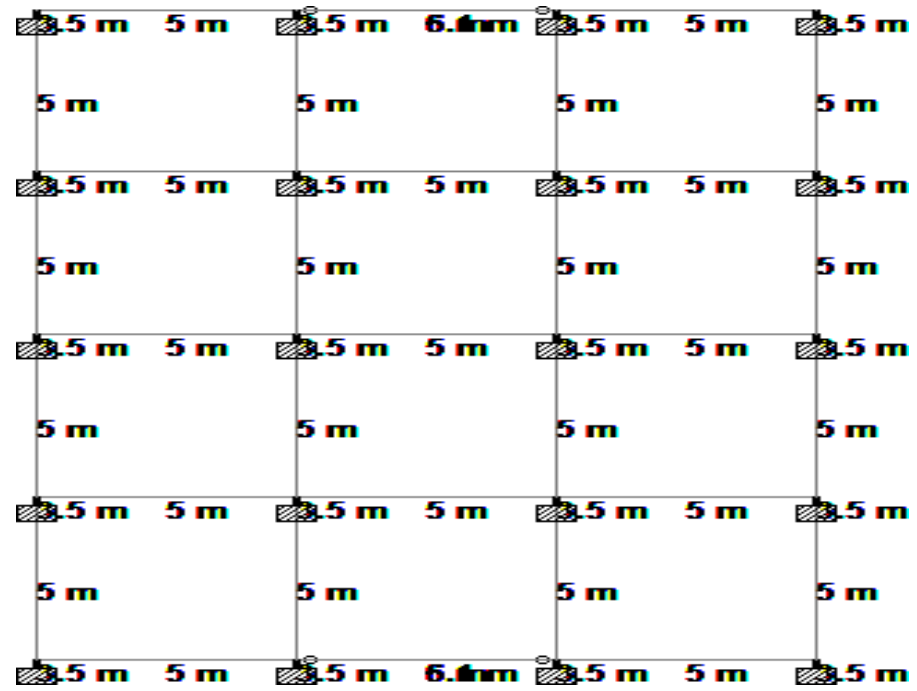

Fig 2.1 Plan of the building

In E tab, Modeling and Analysis is done as follows:

1. After preparing the bare model, seismic definition for IS 1893-2002 was created by giving the required input of time period, zone factor, $\mathrm{R}$ factor, etc. Then under seismic definition self-weight and floor weights of $2.5 \mathrm{kN} / \mathrm{m} 2$ and 3.5 $\mathrm{kN} / \mathrm{m} 2$ weregiven.

2. Under Load Definition Earthquake load, Dead load, Live load and various load combinations werecreated.

3. Under Earthquake load, after assigning self-weight, floor load and live load in $\mathrm{X}, \mathrm{Y}$ and $\mathrm{Z}$ directions,. For Indian Code compatible earthquake already defined IS 1893-2002 is chosen.

4.The load combinations that were considered were according to IS 1893-2002 (Part-1) and are as follows:

1.5(DL+LL) 


\author{
$1.2(\mathrm{DL}+\mathrm{LL}+\mathrm{EL})$ \\ $1.2(\mathrm{DL}+\mathrm{LL}-\mathrm{EL})$ \\ 1.5 (DL+EL) \\ 1.5 (DL-EL) 0.9DL + 1.5 EL 0.9DL -1.5 EL
}

\section{Modelling Of Braced Frame}

For braces angle section ISA $60 \times 40 \times 6$ is used. There are four trial locations in the building where braces are placed and analyzed for their effect on lateral stiffness. Braces are modeled as axial force members having pinned end connections. Bracings are of X-type modeled throughout the height of the building. The four locations are as follows:

Location 1: Bracing A- at the exterior side of the frame along $\mathrm{X}$-direction.

Location 2: Bracing B- at the exterior side of the frame along Y-direction.

Location 3: Bracing AB- at the exterior side of the frame along $\mathrm{X}$ and $\mathrm{Y}$-direction. Location 4: Bracing $\mathrm{C}$ - at the exterior side of the frame around the corners.

The figures of the models with different locations of braces are given in the tables below:

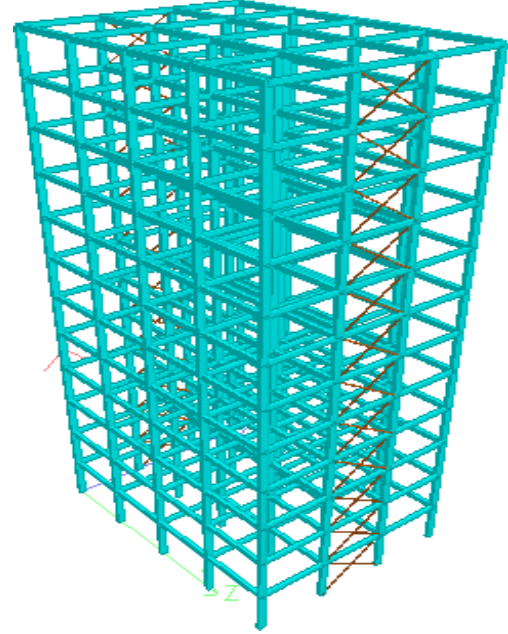

3D Model of the building with braces at location 1

\section{CONCEPTUAL BACKGROUND}

\subsection{Introduction}

In recent years, devastating earthquakes worldwide confirmed the deficiencies of building structures. The experience gained from field observations and back-analysis led to improvement of the level of knowledge and the evolution of seismic codes.

The interest of the research community is focused on buildings that do not comply with current seismic codes and exhibit deficiencies such as poor detailing, discontinuous load paths and lack of capacity design provisions. Since such buildings comprise the majority of existing building stock, retrofitting is a rather critical issue. Rehabilitation schemes that will provide cost-effective and structurally effective solutions are necessary. Many intervention methods used in the past have been revised and developed in the light of the new seismic code requirements and new methods often based on new materials (e.g. fibre-reinforced polymers FRPs) have been proposed.

\subsection{Framework of seismic rehabilitation}

Performance objectives are set depending on the structural type, the importance of the building, its role in post-earthquake emergencies, the economic consequences of business interruption, its historical or cultural significance, the construction material and socio-economic factors. They can be specified as limits on one or more response parameter such as stresses, strains, displacements, accelerations, etc. Clearly, different limit states have to be correlated to the level of the seismic action, i.e. to the earthquake demand level.

\subsection{Injection Of Cracks}

Crack injection is a versatile and economical method of repairing reinforced concrete (RC) structures. The effectiveness of the repair process depends on the ability of the adhesive material (usually epoxies) to penetrate, under appropriate pressure, into the fine cracks of the damaged concrete. Flexural cracks and shear cracks are mainly continuous and therefore provide unobstructed passages for the epoxy. On the other hand, longitudinal cracks, which develop along reinforcing bars as a result of bond failure, are usually discontinuous and narrow. Difficulties may occur in repairing the steel-to-concrete bond by epoxy injection.
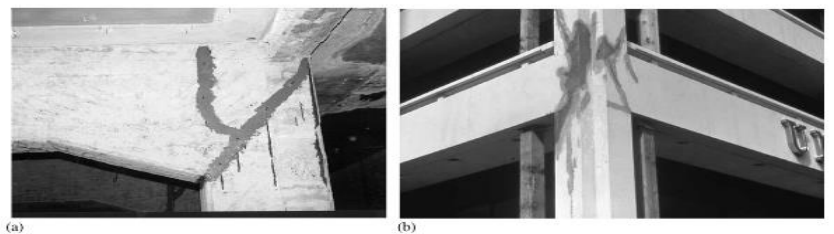

Figure 3. 1Application of the: (a) epoxy resin; (b) cement grout injection in beam-column joints

Flexural tests on RC beams and beam-column joints show that the repair process not only eliminates the unsightly appearance of wide cracks, but also restores the flexural strength and stiffness of the damaged member2, 3. Push-off tests (both static and dynamic) further indicate that concrete-to-concrete joints can regain their shear strength after being repaired by epoxy resin injection.

\subsubsection{Shotcrete (Gunite)}

Shotcrete is used as a repair method for RC and masonry structures. There are two distinct types of shotcrete; dry-mix and wet-mix. Shotcrete can be applied to almost any surface; it can also be used in combination with other retrofit schemes (e.g. RC jacket). Because of its generally low water-cement ratio and high-velocity impact, it achieves excellent bond to most competent surfaces. Deficiencies in shotcrete applicability usually fall into one of the following five categories: (i) failure to bond to the receiving surface, (ii) de-lamination at construction joints or interfaces of various application layers, (iii) incomplete filling of the material behind the reinforcing steel, (iv) slough due to excess mixing water (which can generate voids) and (v) weak interface between the concrete and steel.

\subsubsection{Steel Plate Adhesion}

Steel plate adhesion is mainly used in the case of beams. Both shear and flexural strength enhancement can be achieved. When thick steel plates are needed, it is advisable to use several thin layers instead, to minimize interfacial shear stresses. The execution of the bonding work is also of great importance to achieve a composite action between the adherents. Prevention of premature de-bonding or peeling of externally bonded plates is a most critical aspect of design5-7. 


\subsubsection{Steel jacketing}

The steel jacketing option involves the total encasement of the column with thin steel plates placed at a small distance from the column surface, with the ensuing gap filled with non-shrink grout. An alternative to a complete jacket is the steel cage alternative. Steel angles are placed at the corners of the existing cross-section and either transversal straps or continuous steel plates are welded on them. In practice, the straps are often laterally stressed either by special wrenches or by preheating to temperatures of about $200-400^{\circ} \mathrm{C}$, prior to welding. osion or fire
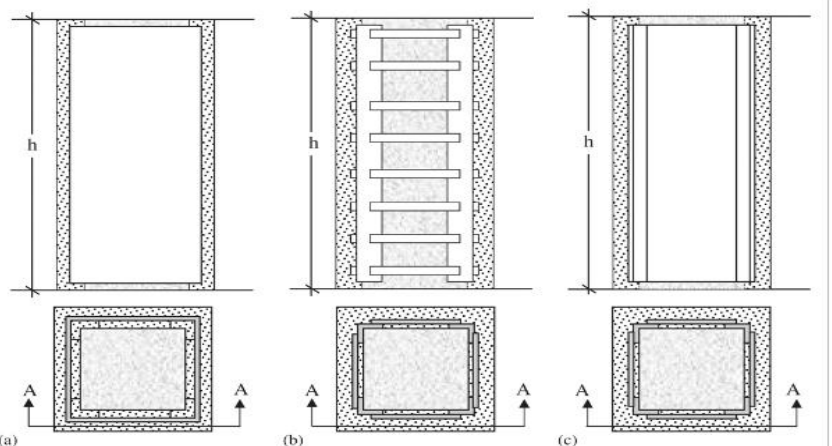

Figure 3. 2 (a) Steel jacketing; (b) steel cage technique using steel straps or (c) steel plates

The corrugated steel jacketing technique can be applied for the rehabilitation of columns and beam-column joints. Deficient connections are encased by the steel jacket and the gap between the concrete and the steel jacket is filled with non-shrink grout. A gap is provided between the beam jacket and the column face to minimize flexural strength enhancement of the beam; which may cause excessive forces to develop in the joint and column.

\subsubsection{Externally bonded FRPs}

The ease of application of FRP composites renders them attractive for use in structural applications; especially in cases where dead weight, space or time restrictions exist. Although FRP composites can have strength levels significantly higher than those of steel and can be formed of constituents such as carbon (CFRP), glass (GFRP), and aramid (AFRP) fibers, it is important to note that its use is often dictated by strain limitations. They are very sensitive to transverse actions (i.e. corner or discontinuity effects) and unable to transfer local shear (i.e. interfacial failure). Clearly, they carry no compressive forces. Choosing the type of fibers, their orientation, their thickness and the number of plies, results in a great flexibility in selecting the appropriate retrofit scheme that allows to target the strength hierarchy at both local (i.e. upgrade of single elements) and global (i.e. achievement of a desired global mechanism) levels. In general, FRP composites behave in a linear elastic fashion to failure without any significant yielding or plastic deformation. Additionally, it should be noted that unlike reinforcing steel, some fibers (such as carbon fibers) are anisotropic.

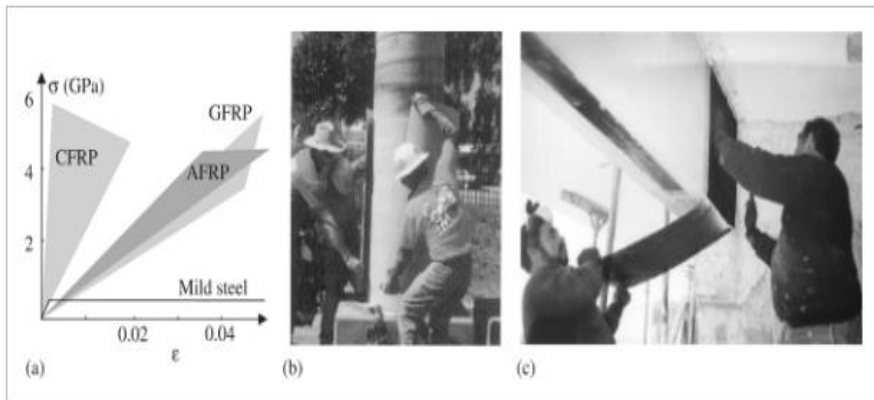

Figure 3 (a) Material properties; application modes of (b) prefabricated shells; (c) FRP sheets

\subsubsection{Selective intervention methods}

Stiffness-only intervention approaches may be used in order to accommodate problems related to irregular distribution of stiffness or to significant reduction of stiffness due to cracking of concrete members. In the latter case, if concrete crushing and buckling of reinforcement bars do not occur the flexural strength of the members will not necessarily be adversely affected.

\section{RESULT AND DISCUSSION}

The result is based on the responses of the bare frame model and the changes in the responses after using bracings and shear wall. The results include changes in base shear, inter-storey drifts and top-storey deflections for ground motions along X and $\mathrm{Z}$ direction considered individually. The results of, base shear, inter-storey drifts and top- storey deflection for bare frame, braced frame and shear wall frame were then compared with each other and a conclusion was then drawn.

\subsection{Comparison of Base Shear for ground motion in $\mathrm{X}$ - direction}

The base shear was found to be increasing from bare frame to braced frame and is even more for frame with shear wall. In case of braced frame highest base shear is found in case of Bracing $\mathrm{C}$ in X-direction. In case of shear wall base shear is highest in case of Shear wall C in X-direction. Shear wall B shows the least base shear among all the shear wall cases because in case of Shear Wall B the frame is stiffened only along $\mathrm{Y}$ - direction and not along $\mathrm{Z}$.

Table 4.1 shows the base shear for ground motion in $X$ direction for all the cases. Fig 5.1. Shows the variation of the base shear

Table 4.1. Base shear for ground motion in X-direction

\begin{tabular}{|c|c|}
\hline Cases & Base Shear (kN) \\
\hline Bare Frame & 558.65 \\
\hline Case A & 678.48 \\
\hline Case B & 562.32 \\
\hline Case AB & 681.95 \\
\hline Case C & 740.62 \\
\hline Shear Wall A & 895.7 \\
\hline Shear Wall B & 658.36 \\
\hline Shear Wall AB & 990.91 \\
\hline Shear Wall C & 1227.99 \\
\hline
\end{tabular}




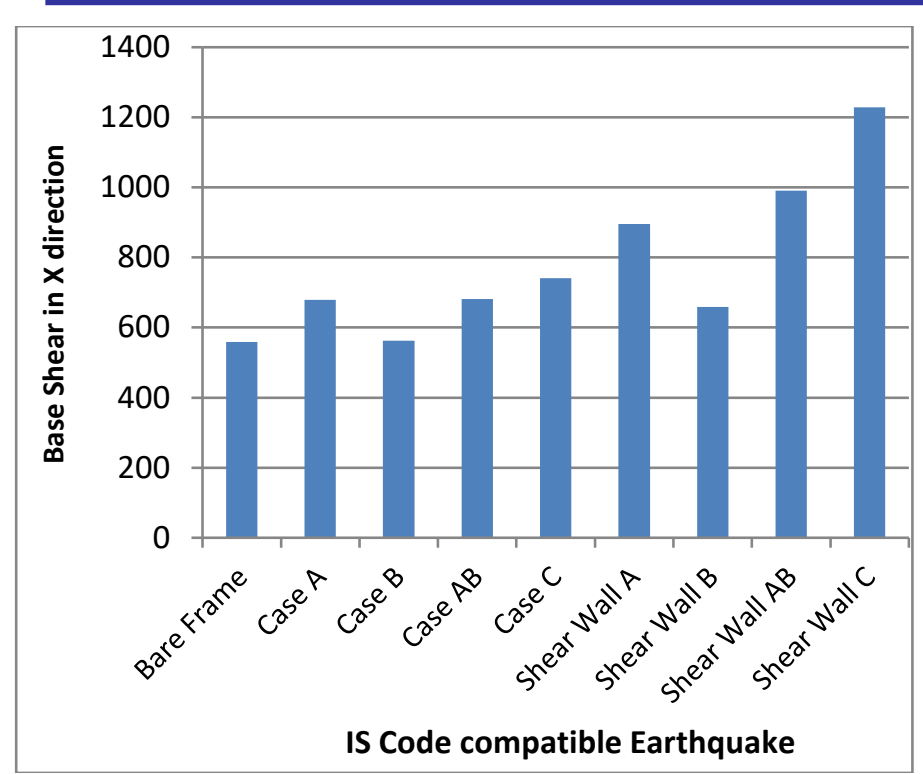

Fig 4.1. Variation of base shear for ground motion in X-direction

\subsection{Comparison of Base Shear for ground motion in Z- direction}

The base shear was found to be increasing from bare frame to braced frame and is even more for frame with shear wall. In case of braced frame highest base shear is found in case of Bracing C in Z-direction. In case of shear wall base shear is highest in case of Shear wall C in Z-direction. Shear wall A shows the least base shear among all the shear wall cases because in case of Shear Wall A the frame is stiffened only along $\mathrm{X}$ - direction and not along $\mathrm{Z}$.

Table 4.2. Base shear for ground motion in Z-direction

\begin{tabular}{|c|c|}
\hline Cases & Base Shear $(\mathbf{k N})$ \\
\hline Bare Frame & 519.54 \\
\hline Case A & 519.36 \\
\hline Case B & 514.35 \\
\hline Case AB & 511.25 \\
\hline Case C & 518.58 \\
\hline Shear Wall A & 563.52 \\
\hline Shear Wall B & 1145.63 \\
\hline Shear Wall AB & 1221.58 \\
\hline Shear Wall C & 1310.55 \\
\hline
\end{tabular}

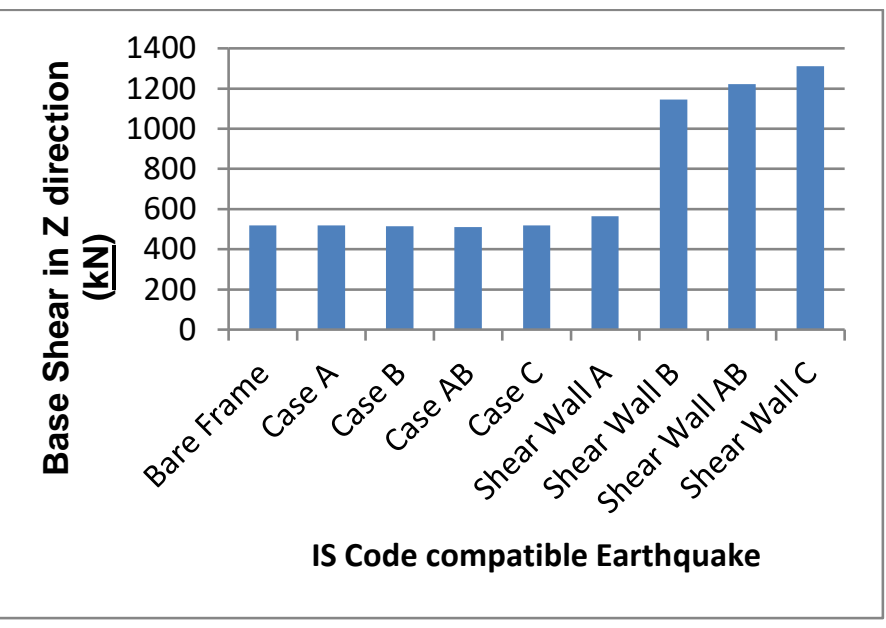

Fig 4.2. Variation of base shear for ground motion in Z- direction
4.3 Comparison of Inter-Storey Drift for ground motion in Xdirection

As per IS 1893-2002 (Part-I) storey drift should be within $0.4 \%$ of storey height. For the building considered in this study the safe limit for storey drift is $14 \mathrm{~mm}$. Inter- storey drifts in bare frame was found to exceed this limit of $14 \mathrm{~mm}$. By using bracings and shear wall in the building the drift is found to be reduced. Inter storey drift decreases remarkably in case of shear walls. For ground motion in X-direction inter-storey drift is minimum in case of Bracing $C$ and Shear Wall C. Shear Wall A shows the least inter- store drift in X-direction than Shear Wall B, because Shear Wall A is along X direction only whereas Shear Wall B is along $\mathrm{Z}$ direction only.

Table 5.3 shows the inter-storey drift for ground motion in Zdirection for all the cases.

Fig 4.3.Shows the variation of inter-storey drift

Table4.3. Inter-Storey Drift for ground motion in Xdirection

\begin{tabular}{|c|c|c|c|c|c|c|c|c|c|}
\hline \multirow[t]{2}{*}{ Storey } & \multicolumn{5}{|c|}{ Bare BracingBracingBracingBracing } & Shear & Shear & Shear & Shear \\
\hline & Frame & A & B & $\mathrm{B}^{\mathrm{A}}$ & $\mathrm{C}$ & Wall A & Wall B & $\begin{array}{c}\text { Wall } \\
\mathrm{AB}\end{array}$ & Wall C \\
\hline 1 & 0 & 0 & 0 & 0 & 0 & 0 & 0 & 0 & 0 \\
\hline 2 & 7.923 & 6.51 & 7.946 & 6.498 & 5.667 & 3.288 & 7.882 & 3.079 & 2.576 \\
\hline 3 & 13.611 & 10.441 & 13.65 & 10.424 & 8.938 & 5.344 & 14.066 & 5.912 & 4.63 \\
\hline 4 & 14.317 & 10.828 & 14.361 & 10.815 & 9.321 & 5.716 & 14.88 & 6.757 & 5.099 \\
\hline 5 & 13.722 & 10.468 & 13.771 & 10.465 & 9.089 & 5.975 & 14.34 & 7.054 & 5.319 \\
\hline 6 & 12.716 & 9.862 & 12.763 & 9.861 & 8.653 & 6.462 & 13.728 & 7.291 & 5.707 \\
\hline 7 & 11.583 & 9.182 & 11.626 & 9.182 & 8.172 & 6.697 & 12.62 & 7.418 & 5.892 \\
\hline 8 & 10.424 & 8.492 & 10.462 & 8.49 & 7.698 & 6.847 & 11.309 & 7.481 & 6.056 \\
\hline 19 & 9.236 & 7.774 & 9.269 & 7.771 & 7.205 & 6.989 & 9.883 & 7.46 & 6.212 \\
\hline 10 & 7.95 & 6.958 & \begin{tabular}{|l|}
7.977 \\
\end{tabular} & 6.954 & 6.611 & 6.915 & 8.412 & 7.212 & 6.168 \\
\hline 11 & 6.484 & 5.96 & 6.506 & 5.965 & 5.824 & 6.53 & 6.681 & 6.684 & 5.884 \\
\hline 12 & 4.812 & 4.739 & 4.828 & 4.735 & 4.791 & 5.976 & 5.08 & 6.054 & 5.379 \\
\hline 13 & 3.251 & 3.222 & 3.522 & 3.254 & 3.256 & 5.214 & 3.256 & 5.321 & 4.256 \\
\hline
\end{tabular}

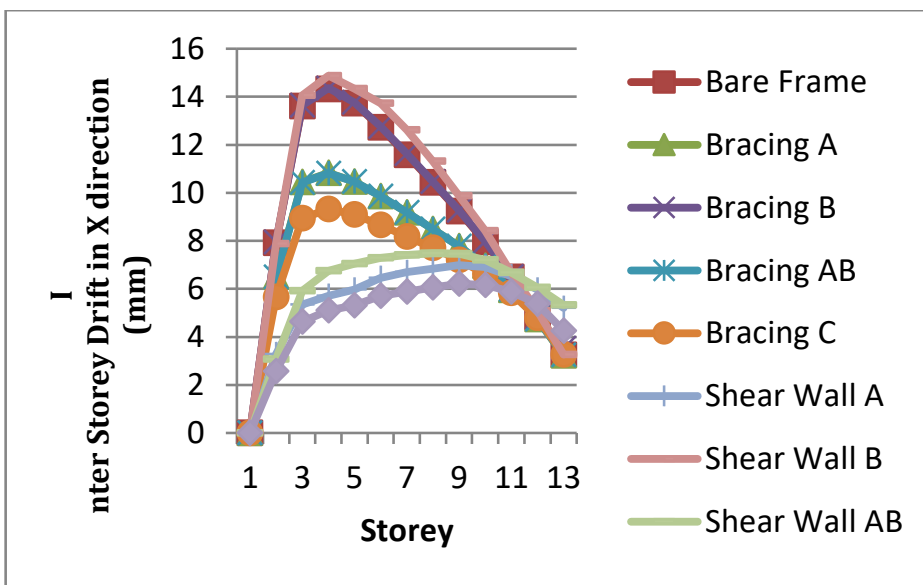

Fig 4.3. Variation of Inter-Storey Drift for ground motion in X direction 


\subsection{Comparison of Inter-Storey Drift for ground motion in Z- direction}

Inter- storey drifts in bare frame was found to exceed this limit of $14 \mathrm{~mm}$. By using bracings it was found that there was no reduction in drift in $\mathrm{Z}$ direction but frame with shear wall showed remarkable reduction in the drift. Inter storey drift decreases remarkably in case of shear walls. For ground motion in Z-direction inter-storey drift is minimum in case Shear Wall C. Shear Wall B shows the least inter-store drift in Z- direction than Shear Wall A, because Shear Wall A is along $\mathrm{Z}$ direction only whereas Shear Wall $\mathrm{A}$ is along $\mathrm{X}$ direction only.Table 5.4 shows the inter-storey drift for ground motion in Z-direction for all the cases. Fig 5.4. Shows the variation of inter-storey drift.

Table 4.4. Inter-Storey Drift for ground motion in Z- direction

\begin{tabular}{|c|c|c|c|c|c|c|c|c|c|}
\hline Storey & Bare & Bracin & Bracing & Bracin & Bracing & g Shear & Shear & Shear & Shear \\
\hline & Frame & A & B & $\mathrm{AB}$ & $\mathrm{C}$ & Wall A & Wall B & Wall & Wall C \\
\hline & & & & & & & & & \\
\hline 1 & 0 & 0 & 0 & 0 & 0 & 0 & 0 & 0 & 0 \\
\hline 2 & 12.527 & 12.483 & 12.49 & 12.306 & 12.484 & 411.848 & 4.011 & 2.695 & 2.759 \\
\hline 3 & 16.019 & 15.963 & 16.021 & 15.841 & 15.963 & 315675 & 4.762 & 4.227 & 4.213 \\
\hline 4 & 15.531 & 15.476 & 16.03 & 16.393 & 15.476 & 515.935 & 3.82 & 4.555 & 4.543 \\
\hline 5 & 14.536 & 14.485 & 15.052 & 15.45 & 14.485 & 515.119 & 3.624 & 4.784 & 4.844 \\
\hline 6 & 13.354 & 13.307 & 13.392 & 13.283 & 13.306 & 513.939 & 4.457 & 5.107 & 5.308 \\
\hline 7 & 12.114 & 12.071 & 12.089 & 11.962 & 12.07 & 12.692 & 5.341 & 5.48 & 5.757 \\
\hline 8 & 10.868 & 10.828 & 10.855 & 10.719 & 10.828 & 811.341 & 5.25 & 5.814 & 6.141 \\
\hline 9 & 9.59 & 9.555 & 9.573 & 9.447 & 9.553 & 9.933 & 5.739 & 6.063 & 6.462 \\
\hline 10 & 8.2 & 8.169 & 8.182 & 8.068 & 8.168 & 8.401 & 5.752 & 6.124 & 6.589 \\
\hline 11 & 6.609 & 6.584 & 6.592 & 6.497 & 6.583 & 6.728 & 5.96 & 5.913 & 6.467 \\
\hline 12 & 4.767 & 4.749 & 4.755 & 4.685 & 4.747 & 4.959 & 5.738 & 5.544 & 6.132 \\
\hline 13 & 2.756 & 2.745 & 2.751 & 2.713 & 2.743 & 3.054 & 5.139 & 4.845 & 5.39 \\
\hline
\end{tabular}

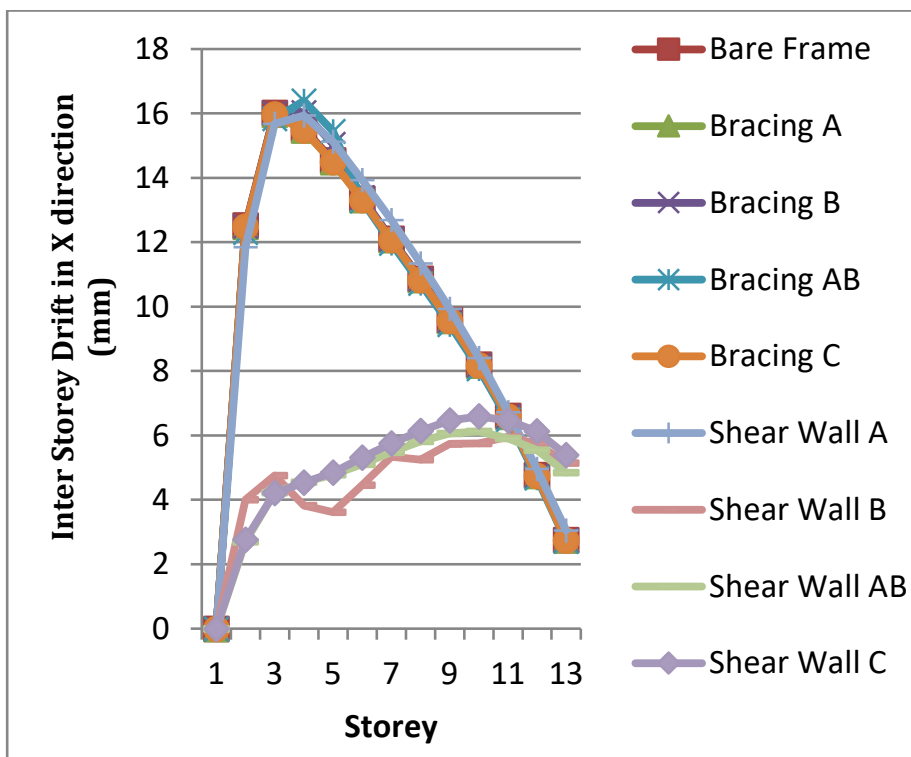

Fig 4.4. Variation of Inter-Storey Drift for ground motion in $\mathrm{Z}$ direction
4.5 Comparison of Top-Storey Deflection for ground motion in $\mathrm{X}$ - direction

There is reduction in top-storey deflection in the frame due to bracing and shear wall. Reduction is more in case of Bracing $\mathrm{C}$ and Shear Wall C. For ground motion in X-direction Shear Wall B is ineffective since in Shear Wall B case shear wall is present in Z-direction not in X-direction.

Table 5.5 below shows the top-storey deflection for each case, Fig 5.5. shows the variation in top-storey deflection in $\mathrm{X}$ direction and Fig.5.6 shows the Etab results for top-storey deflection.

Table 4.5. Top-Storey Drift for ground motion in Xdirection

\begin{tabular}{|c|c|}
\hline Cases & Top- Storey Deflection(mm) \\
\hline Bare Frame & 105.876 \\
\hline Bracing A & 80.129 \\
\hline Bracing B & 84.483 \\
\hline Bracing AB & 75.551 \\
\hline Bracing C & 54.88 \\
\hline Shear Wall A & 108.349 \\
\hline Shear Wall B & 56.836 \\
\hline Shear Wall AB & 42.696 \\
\hline Shear Wall C & 105.876 \\
\hline
\end{tabular}
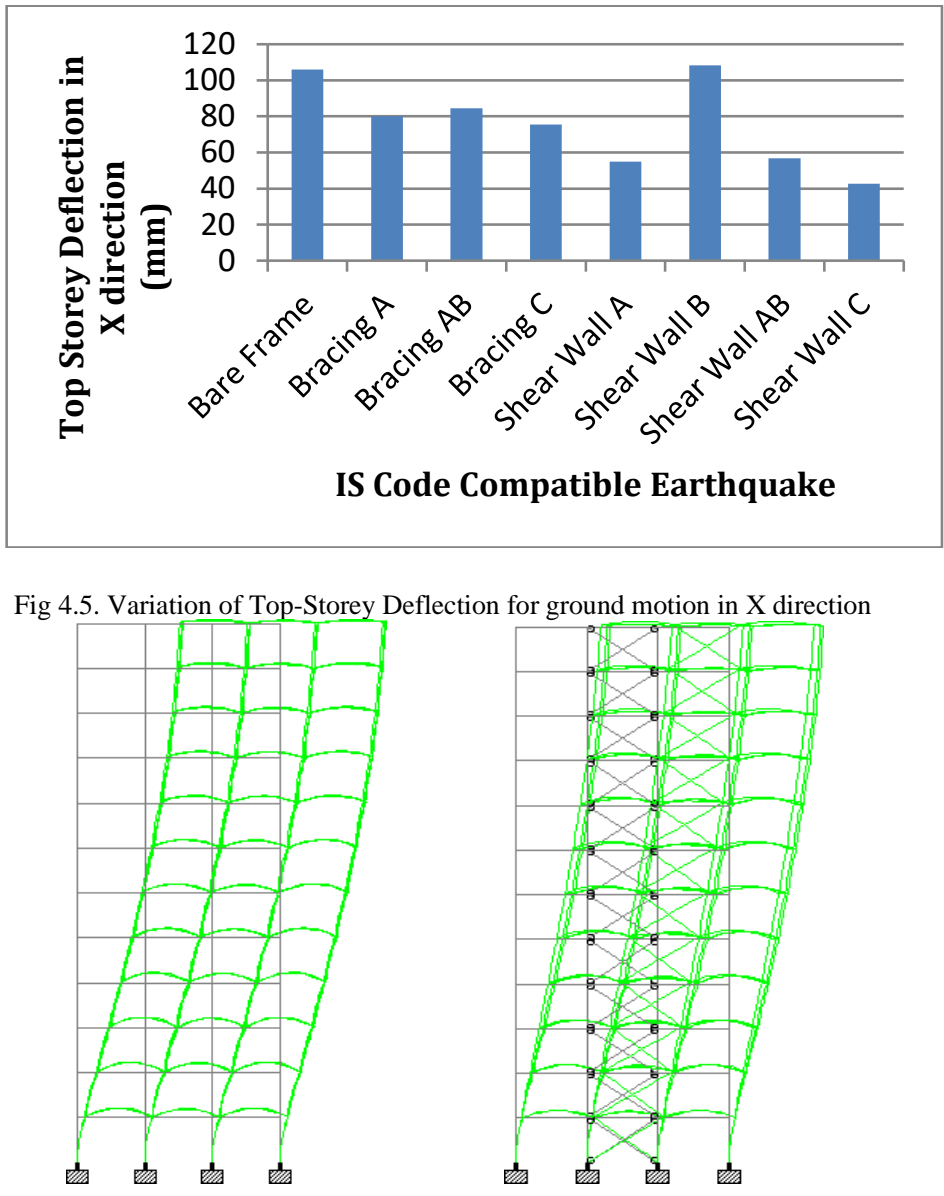

Bare Frame

Bracing A 


\subsection{Comparison of Top-Storey Deflection for ground motion in Z- direction}

Bracings were found to be ineffective in reducing top-storey deflection in $\mathrm{Z}$ direction in the frame. But there is remarkable reduction in top-storey deflection in $\mathrm{Z}$ direction due to shear wall. Reduction is more in case of Shear Wall C. For ground motion in Z- direction Shear Wall A is ineffective since in Shear Wall A case shear wall is present in $\mathrm{X}$-direction not in Z-direction.

Table 5.6 below shows the top-storey deflection for each case, Fig 5.7 shows the variation in top-storey deflection in $\mathrm{Z}$ direction and Fig 5.7. shows the Etab results for top-storey deflection.

Table 4.6. Top-Storey Drift for ground motion in Z- direction

\begin{tabular}{|c|c|}
\hline Cases & $\begin{array}{c}\text { Top- Storey Deflection } \\
(\mathbf{m m})\end{array}$ \\
\hline Bare Frame & 116.355 \\
\hline Bracing A & 116.385 \\
\hline Bracing B & 132.365 \\
\hline Bracing AB & 131.377 \\
\hline Bracing C & 150.214 \\
\hline Shear Wall A & 108.366 \\
\hline Shear Wall B & 59.63 \\
\hline Shear Wall AB & 49.365 \\
\hline Shear Wall C & 58.939 \\
\hline
\end{tabular}

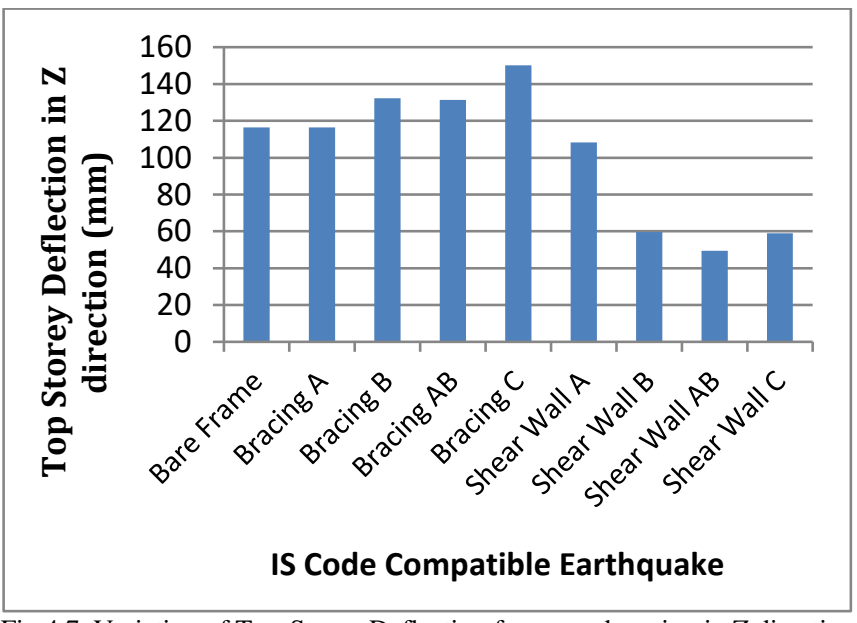

Fig 4.7. Variation of Top-Storey Deflection for ground motion in Z direction

\section{CONCLUSION}

This project work was a small effort towards perceiving the how introducing bracing or a shear wall in a building can make in difference in protecting the building in earthquakes. Almost all the buildings in India are RC frame, and earthquake tremors are felt every now a then in some or the other part of the country. Hence through this project it was tried to appreciate the effectiveness and role of this small extra structural elements that can save both life and property, at least for most of the earthquakes.

The following conclusions were drawn at the end of the study:

$>$ Base Shear produced in the Bare Frame is maximum for Shear wall at C.

> In case of bracing system, Bracing System C (with braces at the corners) are the most effective one than other bracing systems, effectively reducing top-storey drift and inter storey drifts in both $\mathrm{X}$ - and Zdirections.

> There is hardly any reduction in drift along Zdirection due to Bracing $\mathrm{B}$, for all the ground motions.

$>$ Shear Wall A is effective in reducing drifts along Xdirection only, and Shear Wall B is effective in reducing drifts along $\mathrm{Z}$ - direction only, for all the ground motions.

$>$ Above all Shear Wall $\mathrm{C}$ is the best in all the stiffening cases considered.

$>$ Shear wall elements are very much efficient in reducing lateral displacement of frame as drift and horizontal deflection induced in shear wall frame are much less than that induced in braced frame and plane frame

$>$ The location of shear-wall and brace member has significant effect on the seismic response than the plane frame

$>$ Shear wall construction will provide large stiffness to the building by reducing the damage to the structure.

\section{REFERENCES}

[1] Chandurkar P. P, Dr. Pajgade P. S. (2013). "Seismic Analysis of RCC Building with and Without Shear Wall." , International Journal of Modern Engineering Research (IJMER) (2249-6645).

[2] Chavan Krishnaraj R. ,Jadhav H.S. (2014). "Seismic Response of RC Building With Different Arrangement of Steel Bracing System.”, International Journal of engineering Research and Applications (2248-9622)

[3] Esmaili O, et al. (2008). "Study of Structural RC Shear Wall System in a 56- Storey RC Tall Building.”, The 14th World Conference on Earthquake Engineering October 12-17, 2008 , Beijing, China.

[4] Akbari R.et al. (2014). "Seismic Fragility Assessment of Steel XBraced and Chevron- Braced RC Frames.", Asian Journal of Civil Engineering (BHRC), VOL- 16 No.1

[5] Kappos Andreas J., Manafpour Alireza (2000). "Seismic Design of R/C Buildings with the aid of advanced analytical techniques." Engineering Structures 23 (2001) 319-332.

[6] Yamada M. et al. " Multistorey Bracing Systems of Reinforced Concrete and Steel - Rigid Frames Subjected To Horizontal LoadsProposition of Total Evaluation on the Aseismic Capacity for Design."

[7] Viswanath K.G. et al.(2010). "Seismic Analysis of Steel Braced Reinforced Concrete Frames." International Journal of Civil \& Structural Engineering (0976-4399).

[8] A.E Hassaball, "Seismic analysis of a RC building by RSM", IOSR journal of engineering, volume 3, Issue 9, ISSN:2250-3021, September 2013.

[9] Sagar R. Padol, "Review paper on seismic response of multistoried RCC building with mass irregularity" International journal of research in engineering and technology. ISSN: 2321-7308.

[10] Girum mindaye, "Seismic analysis of multistory RC frame building in different seismic zone", International Journal of Innovative Research in Science, Engineering and Technology, vol.-05, issue09, sep.2016.

[11] Patil A.S, Kumbhar P.D, "Time history analysis of multistoried RRC building for different seismic intensities", International Journal of Structural and Civil Engineering Research, vol.-02, issue-03, Aug 2013.

[12] Bhagwat Mayuri D, "Comparative study of Performance of multistoried building for Koyna and Bhuj earthquake by THM and RSM", International Journal of Advanced Technology in Engineering and Science, vol.no.-02, issue- 07, ISSN:2348-7550, July 2014.

[13] Dubey S.K, Sangamnerka Prakash, Agrawal Ankit, "Dynamic analysis of structures subjected to earthquake load", International 
Journal of Advance Engineering and Research Development, vol.02, issue-09, ISSN:2348-4470, Sep.2015.

[14] Rampure Aarti baburao, "Comparison between Response Spectrum Method and Time History Method of dynamic analysis of concrete gravity dam", Open Journal of Civil Engineering,June 2016.

[15] Hawaldar Jyothi C, "Earthquake analysis of G+12storey building with and without infill for Bhuj and Koyna earthquake function", International Research Journal of Engineering and Technology(IRJET), vol.-2, issue-05,ISSN:2395-0056, august 2015.

[16] Bahador Bagheri, "Comparative study of the static and dynamic analysis of multistorey irregular building", International Journal Civil, Environmental Structural Construction and Architectural Engineering, vol-6.

[17] Harshita, "seismic Analysis of symmetric RC frame using RSM and THM", International Journal of Scientific Research and Education, vol-02,issue03, march 2014.

[18] Amit A Sathawane and R. S. Deotale (2012), "Analysis of Flat Slab and Grid Slab and Their Cost Comparison", International Journal of Advanced Technology in Civil Engineering, ISSN: 2231-5721, Vol. 01, Issue 02, pp.122-126. 